should take plenty. The body needs more food to sustain it in an extremely cold climate than in the lower latitudes, especially when con tinually employed in arduous outdoor work. To withstand the cold one needs a large amount of such food as beans, rice, meal and flour, two dozen bars of soap, mustard, Jamaica ginger, and a half tin of matches. A small medicine case well stocked with standard preparations is necessary, and quinine and calomel should always form a part tions is necessary, and quinine and calomel should always form a part. of ordinary vinegar, and citric acid will make lemonade and also preof ordinary

"In the way of groceries we suggest the following for one man for a year : $350 \mathrm{lbs}$. of flour, , $150 \mathrm{lbs}$. of bacon, $100 \mathrm{lbs}$. of beans, $15 \mathrm{lbs}$. of tea $25 \mathrm{lbs}$. of rice, 5o lbs. of dry alt pork, roo lbs. of dried fruits, $50 \mathrm{lbs}$. o salt (for canning and cooking), 2 lbs. of evaporated vinegar, $201 \mathrm{lbs}$. of condensed milk, $50 \mathrm{lbs}$. of corn meal, 50 lbs. of rolled oats, 30 lbs. of coffee, roo lbs. of sugar, 25 lbs. of dried beef, 40 lbs. of evaporated potatoes, 15 lbs. of evaporated onions, ro lbs. of baking powder, 12 lbs. of condensed soup. In addition, each man should have a gold pan, a pick, shovel, axe, and hatchet, a pocket compass, a stout clasp knife, a pair of snow glasses to save the eyes from the glare of sunlight on snow ; a rifle or shot gun is also useful. As to clothing, a full equipment for each man should consist of the best quality woollens, both suits and undergarments, mocassins, high india-rubber boots; also furs
are necessary. The prospector will also need a tent, stove, gold scales,

are necessary. The prospect

"The following suggestion will be found useful: For frozen fingers use cold water. Nowhere are mosquitos so numerous. There are two kinds of poisonous flies. The best protection is silk tissue, not gauze Do not eat snow or ice : melt them. Use blankets in summer and avoid rheumatism."

ASEPTIC MIDWIFERY : A CORRECTION

DR. JARDINE (Glasgow) writes: In reference to Dr. Newell's note, he is quite right. If it had been $r e$ instead of on it would not have made any difference. I regret exceedingly that space did not allow me to take up his letter paragraph by paragraph. To have done so would have up his letter paragraph by paragraph. To have done so would have my article before me when I wrote, which I am inclined to think few of my critics seem to have had, judging from the number of misrepresentations indulged in. When he was at it he might also have corrected a mistake in one of his quotations. He is quite welcome to his opinion that my reply was childish, and for that matter so is any other man who thinks reply was childish, and for that matter so is any other man who thinks still a considerable distance from my dotage.

The Royal ARMy Medicat Corps.

Adverting to the short article in the British Medical Journal of November rath, H. writes: It is important to would-be candidates for the next examination in February to know that there is now required from all candidates a definite standard in height, chest measurement, and weight. At the last examination several candidates were rejected on one or other, or all, of these grounds to whom it would have been a distinct advantage to have known before going through special instruction and preparation for the examination that they did not reach the required standard. Candidates for the R.A.M.C. have alluded to.

The Gentle Art of Advertisement.

To the philosophic student of the current literature of the present day nothing is more amusing, and in its way instructive, than the ingenuity with which the advertiser turns everything to favour-to his own favour, that is-if not always to prettiness. In connection with the recent visit of English pilgrims to Rome, it is stated that among the presents sent to the Pope was "a case of clinical thermometers of the pattern employed by Mr. Gladstone in his last illness, and adopted by Sir Morell Mackenzie for use in the case of the late Emperor Frederick." These interesting objects were presented by a London manufacture. who was doubtless actuated solely by the wish to show his respect for the Holy Father, who, being presumably a connoisseur in relics, may naturally be supposed likely to accept a new variety with enthusiasm. But persons of sordid mind will probably see in the gift a desire on the part of the eminent manufacturer to add the Pope to the list of august patients who have used his thermometers.

LARGE FoETUS.

Dr. P. O'Connell (Stillorgan Castle, co. Dublin) writes: The note of Dr. Arthuir Dobson, in the BRITISH MEDICAL JoURNaL of September 17 th, p. 848, reminds me that in 1890 I attended a woman in her fourth labour, when slie gave birth to such an unusually large and broad-shouldered child (a male) that I weighed it. Its weight was just 15 lbs. No injury was done to the perineum. Two years later I again attended the same patient in labour, when she gave birth to twins-a male and female-and each child weighed ir lbs.

\section{Medical Fefs for Life insurance Examinations.}

REFFRF writes: I reply to "General Practitioner" re above. I beg to statc 1'1.:t the New York Mutual Insurance Company pay a fee of one guiuca tor medical examination for any sum assured up to $€ 5,000$, if ave that sum they pay a fee of

It is time we took a stand on this insurance question. The low fees the Accidental Companies are paying under the Workmen's Compensation Act is absurd (2s. 6d. for visit and report), in fact one company is only paying 2 . for a visit and report in this district. Most of these companies actually refuse mileage, and the surgeon has sometimes to travel from two to four miles, and write a report for $2 \mathrm{~s}$. $6 \mathrm{~d}$.
good standing in this district have accepted these terms.

LETTERS, OOMMUNIOATIONS, ETO., have been reoelved from

A Mr. R. B. Anderson, London; Mr. C. J. Aitken, Bedford; Mr. S. Andrews, Basingstoke; Mr. M. F. Agar, London; Army Medical Offcer; J. M. Atkinson, M. B., Hong Burns, M.B., Walls, N.B.; Messrs. Burroughs, Wellcome and Co., London; Mr. T. Blair,
Leeds; Mr. B. Beheim-Schwarzbech, Bloemfontein; Dr. J. T. Bays, Grahamstown; Mr. L. Browne, London; British Orthopedic Society, The Secretary of the, London; Dr. A. G. Barrs, Leeds; Mr. H. Blau, London; Messrs. T. B B. Browne, Limited, London; Messrs. Blandy Brothers and Oo., London; Mr. W. B. Bale, Stookport; Mr. D. A. Bidwell, London; Mr. E. Blake, Portsea ; J. W. Batterham, M. B., St. Leonard's-on-Sea.
C Dr. G. W. Crowe, Worcester; A. Cox, M.B., Gateshead; Mr. E. C. Cripps, Cirencester; C Dr. G. W. Crowe, Worcester; A. Cox, M.B., Gateshead; Mr. E. C. Cripps, Cirencester; Brighton; Dr. W. H. Calvert, Melrose; Mr. C. Corben, Caldicot; Colonial ; Olinioal Society of London, The Honorary Secretary of the, London; E. Du Oane, M.B., Swindon; Cargona Company, Peterborough. I W. B: Drummond, M.B., Edinburgh; Mr. H. H. C. Dent, Birmingham; Dr. A. T. Davies, London. B W. McA. Eccles, M.B., London; Edinburgh; Mr. L. D. L. Ellis, Folkestone; Flberfeld Farben Fabriken Company, London. F Mr. H. Farrell, London; Mr. W. T. Freeman, Reading; Messrs. Fassett and Johnson, London; Dr. T. Fentem, Bakewell; F. M. G Mr. G. P. Gaskell, London; D. MoJ. Glen, M.B., Rutherglen; Dr. H. L. Gordon, London; J. G. Gornall, M.B., Warrington; Dr. J. Gairdner, Crieff; Mr. J. Gay. London. 1 Mr. W. J. H. Haslett, Sunbury-on-Thames; Mr. T. G. Horder, Cardiff; Mr. G. S. Haynes, London; Mr. W. F. Haslam, Birmingham; Messrs. C. J. Hewlett and Son, London; Dr. M. L. Hepburn, South Lowestoft; Dr. J. E. Hare, London; Dr. T. W. Hime, Bradford. J J. M. Y.; Dr. R. Jardine, Glasgow; Mr. S. E. Jones, Bangor Is-y-coed; Dr. 'J. Johnston, Bolton; Jenner Institute for Calf Lymph, The Manager of the, London.
K Dr. R. Kirk, Glasgow; L. F. B. Knuthsen, M.B., Falmouth; Mr. C. W. Krohne, London. I Dr. C. Lamplough, Chatteris ; Mr. M. Lomax, Leamington; Dr. G. H. Lang, Bromley ; Mr. H. Lawrence, London; W. Leask, M.B., Birkenhead; Mr. C. W. Lawson, Gilsland; Dr. T. G. Lyon, London; Leeds and West Riding Medico-Chirurgical Society, The Secretary of i the, Leeds; Mr. P. G. Lee, Cork; Laddie; Dr. J. F. Le Page, Man-
hhester. chester. II Mr. S. R. R. Matthews, London; C. Martin, M.B., Birmingham; Mr. F. H.
Mertens, London; Dr. J. MoNamara, London; Mr. F. W. D. MeGachen, Brotton; Dr. T. Mertens, London; Dr. J. MoNamara, London; Mr. F. W. D. McGachen, Brotton; Dr. T. evoy, London; Dr. W. Milligan, Manchester. if Mr. R. Napier-Jones, London; Dr. W. H. Neale, London; Mr. G. W. Niven, Greenock; Dr. J. C. F. Naumann, London. P Mr. F. E. Pirkis, Nutfleld; Dr. J. Polan, Warsaw; Preparatory School Master ; Dr. W. R. Parker, Kendal; Mr. J. F. Pink, London; Mr. H. J. Palmer, Gamlingay. R Mr. T. F. Raven, Broadstairs; Dr. L. Roberts, Liverpool ; J. S. Riddell, M.B., Aberdeen; Dr. J. A. Rigby, Preston : Dr. E. S. Reynolds, Manchester; Dr. J. J. Ridge. Bnfleld; Referee; Dr. A. C. F. Rabagliati, Bradford; Mr. R. H. F. Routh, Bridgwater; Dr. W. hobertson, Perth. T. T. Streate d, M.B.; Mr. G. A. G. Simpson, London; Mr. S. Snell, ham; Dr. J. A. Shaw-Makenzie, London; Mr. G. A. G. Simpson, London; Mr. S. Snell, Dublin; Rev. L. H. Squire, Kenley ; Mr. J. Snowman, London; Mr. W. P. Stocks, Salford; Dr. G. J. Sealy, Weybridge; Mr. F. P. Sturridge, Kendal; Mr. L. S. Smith, Bir mingham; Mr. R. W. Stewart, Dunfermline. T Mrs. Alec Tweedie, London; Mr. L mingham; Mr. R. W. Stewart, Dunfermline. T Mrs. Alec Tweedie, London; Mr. L. Tallerman, London; Truth; R. Turner, M.B., Eastwood; Dr. Mary Thorne, London True Admirer and Follower on Honest Dr. John Snow; A. Trethewey, M.B., Wrexham V Valentine Extract Company, London ; Mr. G. Veale, Leeds. Wr G. F. Welsford, M.B.,
Tiverton; Dr. J. J. Walsh, New York ; Mr. W. B. Woodhouse, London; Dr. F. WillTiverton; Dr. J. J. Walsh, New York; Mr. W . B. Woodhouse, London; Dr. F. WillDr. A. T. T. Wise, Montreux: Dr. F. J. Waldo, London; Dr. W. IWoodward, Worcester;
W. L. O. Williams, M.B., Llanberis; Mr.' F. White, Coventry; J. R. Watt, M.B., Ayr, etc.

\section{BOOKS, ETo., RECEIVED.}

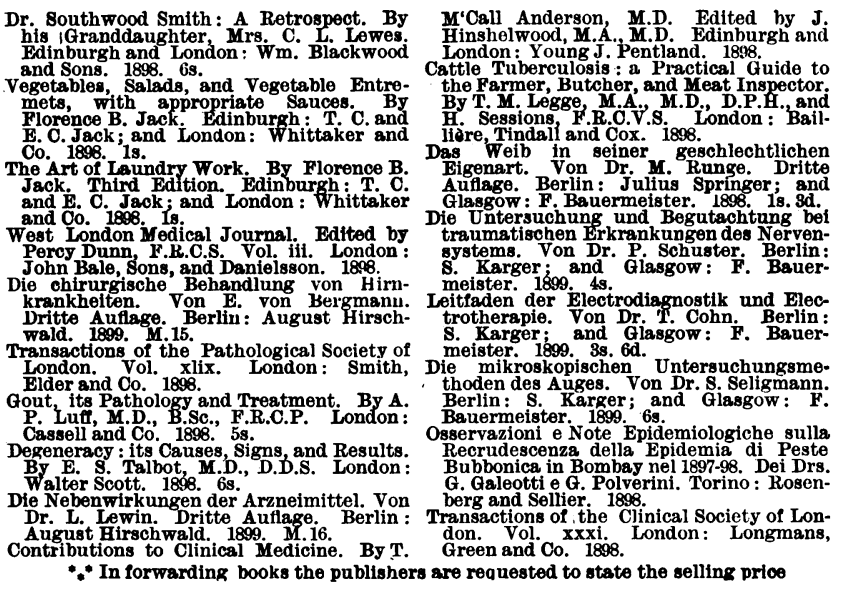

HCAIE OF CHARGES FOR ADVERTIBGMENTS IN THE BEITISE MIDICAT JOURNAT.

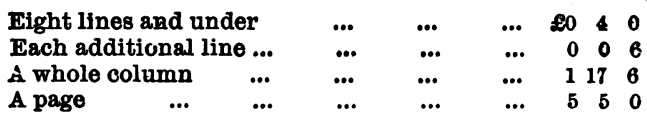

An average line contains $\dddot{\text { six }}$ words.

Advertisements should be delivered, addressed to the Manager, at the Office, not later than noon on the Wednesday preceding publication ; and if not paid for at the time, should be accompanied by a reference.

Post-Office Orders should be made payable to the British Medioed Asso ciation at the General Post-Office, London. Small amounts may be paid in postage-stamps.

N.B.-It is against the rules of the Post Office to receive latters at Poste Restantes addressed either in initials or numbers. 